\title{
RHEOLOGICAL BEHAVIOR OF MIXED DRINK OF ANNONA AND MILK
}

\author{
MARIA E. M. DUARTE ${ }^{1}$, DEYZI S. GOUVEIA ${ }^{2}$, MARIO E. R. M. C. MATA ${ }^{3}$, \\ ALEXANDRE J. DE M. QUEIROZ ${ }^{4}$
}

\begin{abstract}
In this study the rheological behavior in different temperatures $\left(0 ; 6 ; 18\right.$ e $\left.24{ }^{\circ} \mathrm{C}\right)$ and physicochemical parameters of integral annona (Annona squamosa) pulp and the annona pulp with milk in different percentages pulp/milk $(75 \mathrm{~g}$ of annona pulp $/ 25 \mathrm{~g}$ of milk, $50 \mathrm{~g}$ of annona pulp $/ 50 \mathrm{~g}$ of milk, $25 \mathrm{~g}$ of annona pulp/75g of milk) have been availed, in order to verify the effect of temperature and pulp concentration in the rheological behavior of these beverages. To obtain the rheological parameters a concentric cylinder rheometer has been used and the rheograms were analyzed using the Ostwald-de-Wael (power Law) and Herschel-Bulkley models. The physicochemical parameters (sugars, $\mathrm{pH}$, ash, acidity and soluble solids) were determined in order to establish correlations with the rheological behavior. Finally, the best results had been obtained using the Herschel-Bulkley model; the low values for the behavior index $(\mathrm{n}<1)$ obtained confirm the pseudoplastic behavior of all samples.
\end{abstract}

KEYWORDS: fruit, rheology, agro- industry, processing.

\section{COMPORTAMENTO REOLÓGICO DE BEBIDA MISTA DE PINHA E LEITE}

RESUMO: Estudou-se o comportamento reológico em diferentes temperaturas $\left(0 ; 6 ; 18\right.$ e $\left.24{ }^{\circ} \mathrm{C}\right)$ e os parâmetros físico-químicos da polpa de pinha (Annona squamosa) integral e também da polpa de pinha com diferentes percentuais de leite ( $75 \mathrm{~g}$ de polpa de pinha/ $25 \mathrm{~g}$ de leite; $50 \mathrm{~g}$ de polpa de pinha/50g de leite; $25 \mathrm{~g}$ de polpa de pinha/75g de leite), com o intuito de verificar o efeito da temperatura e da concentração de polpa no comportamento reológico desses blends. Para a obtenção dos parâmetros reológicos, foi utilizado um reômetro de cilindros concêntricos. Os parâmetros físico-químicos das formulações $\mathrm{pH}$, acidez total titulável, sólidos solúveis totais, sólidos totais e cinzas foram determinados com o intuito de correlacioná-los com o comportamento reológico obtido. Os reogramas foram analisados utilizando os modelos de Ostwald-de-Wael (Lei da Potência) e Herschel-Bulkley. Os melhores resultados foram obtidos usando o modelo de HerschelBulkley, e os baixos valores obtidos para o índice de comportamento $(n<1)$ confirmam o comportamento pseudoplástico de todas as amostras.

PALAVRAS-CHAVE: fruta, reologia, agroindústria, processamento.

\section{INTRODUCTION}

There are many Brazilian fruits processed in the form of pulps and juices (SANTANA et al., 2008) and others, although well accepted for its taste, are not yet industrialized, among these is the sugar apple (Annona squamosa). The family Annonacea is composed of approximately 120 genera distributed in tropical and subtropical regions around the world, in which Annona is the most important genus within this family, with about 50 species. In the domestic market, lower prices are charged for this fruit in the months of January to mid-March, with a significant increase from April to August (ACAGA \& HAL, 2006).

\footnotetext{
${ }^{1}$ Doutor, Profa. Associado III, Departamento de Engenharia Agrícola, CTRN/UFCG Campina Grande - PB, Fone: 83-2101.1552, melitamd@gmail.com.

${ }^{2}$ Mestre, Profa. Assistente, Depto. de Engenharia Agrícola, CTRN/UFCG, Campina Grande - PB, deyzigouveia@ yahoo.com.br.

${ }^{3}$ Prof. Associado III, Departamento de Engenharia Agrícola, CTRN/UFCG, Campina Grande - PB, mmata@ deag.ufcg.edu.br.

${ }^{4}$ Prof. Associado III, Departamento de Engenharia Agrícola ,CTRN/UFCG, Campina Grande - PB, alex@deag.ufcg.edu.br.

Recebido pelo Conselho Editorial em: 5-4-2011

Aprovado pelo Conselho Editorial em: 10-11-2011
} 
There is much interest from major industries in the knowledge of the physical properties of fruit pulps, in view of the rapid growth in national production of juices (SANTANA et al., 2008) and also nectars, ice creams, desserts, gelled, yogurt among others, where the fruit is generally used as raw material in the form of concentrated pulp.

To take advantage of this emerging market, by providing lower loss than the export of fresh fruits, it can guarantee higher profits for exporters; certain domestic industries begin to study the physical characteristics and behavior of certain products to designing new ways of processing. This knowledge is essential to the specific projects of industrial plants, piping, sizing of pumps and stirring and mixing systems, which precede the arrival of the juices on the shelves of supermarkets (TORALLES et al., 2006, VIDAL et al., 2006; SATO \& CUNHA, 2007).

The viscosity is the resistance of fluids to flow and it can be considered synonymous with internal friction. Otherwise it can be said that the viscosity corresponds to the internal friction in the fluid due primarily to intermolecular interactions, it is often a function of temperature. The force per unit area required to produce motion is called the shear tension, $\tau$, is proportional to the velocity gradient or strain rate, $\gamma$. The proportionality constant between the two is called the consistency index, $\mathrm{k}$ (VIDAL et al., 2006).

According to FERNANDES et al. (2009), the fluids that obey Newton postulate are called Newtonian fluids. The flow occurs as soon as voltage is applied, and the coefficient of viscosity is independent of strain rate and shear tension, and the behavior exponent, $\mathrm{n}$, equal to 1 . The consistency coefficient $(\mathrm{k})$, this case is referred to as viscosity and is represented by $\mu$. The rheological behavior of fruit pulp in general cannot be described by a Newtonian equation. The nonNewtonian fluids are characterized by apparent viscosity $\eta$ at a strain-specific rate. The words used to describe the rheological behavior of fluids that do not change their behavior over time are Equation (1) Herschel-Bulkley (OLIVEIRA et al., 2009, OLIVEIRA et al., 2011).

$$
\tau-\tau_{\mathrm{OH}}=\mathrm{K}_{\mathrm{H}} \dot{\gamma}^{\mathrm{nH}}
$$

In which,

$$
\begin{aligned}
& \tau \text { - shear tension, } \mathrm{Pa} ; \\
& \tau_{O H} \text { - initial tension, } \mathrm{Pa} ; \\
& \mathrm{n}_{\mathrm{H}} \text { - fluid behavior index, dimensionless; } \\
& \mathrm{K}_{\mathrm{H}} \text { - consistency factor (Pa.s), and } \\
& \dot{\gamma} \text { - strain rate, } \mathrm{s}^{-1} \text {. }
\end{aligned}
$$

The food fluids generally is a special case of this expression, in which the threshold voltage of flow $(\tau 0)$ is null or is assumed to be zero, so that eq.(1) becomes eq.(2), known as Ostwald-deWaelle model or Power Law (FERNANDES et al., 2009):

$$
\tau=k \dot{\gamma}^{n}
$$

In which,

$\tau$ - shear tension, $\mathrm{Pa}$;

$\dot{\gamma}$ - strain rate, $\mathrm{s}^{-1}$, and

$\mathrm{K}-$ consistency index (Pa.s).

The objective of this study was to evaluate the effect of temperature and the proportion of pulp in the rheological behavior of drinks made with sugar-apple pulp and milk. 


\section{MATERIAL AND METHODS}

The sugar-apples (Annona squamosa L.) were obtained from farmers in the state of Paraiba. It was chosen the best looking fruit, opting for firmer fruits, without apparent damage in the skin and in mature stage. The fruit pulp was manually extracted, proceeding the removal of the seeds, and then carrying out the homogenization of the pulp in a blender. In addition to the whole pulp three formulations were prepared of milk sugar-apple pulp, using the following proportions (pulp weight / weight of milk): $75 / 25,50 / 50$ and $25 / 75$. The formulations were prepared in a blender to ensure perfect homogeneity.

Rheological measurements were performed on a Brookfield viscometer, model LV - DVII. The study of the rheological behavior was carried out at temperatures of $0 ; 6 ; 12 ; 18$ and $24{ }^{\circ} \mathrm{C}$ and measurements were made by varying the strain rate from 0.22 to $44 \mathrm{~s}^{-1}$ and 0.34 to $68 \mathrm{~s}^{-1}$. The experiments were performed in triplicate using, for each repetition, a new sample equal to the previous one to avoid possible effects of time. The speeds $1 ; 5 ; 10 ; 15 ; 30 ; 60 ; 90 ; 120 ; 150 ; 180$ and $200 \mathrm{rpm}$ were used. The measurements were performed with the use of the spindles 25 and 31 and the torque readings always performed after the first 30 seconds of shear. The experimental data obtained for each sample at different temperatures were correlated by two rheological models: Ostwald-de-Waelle (Power Law) and Herschel-Bulkley. The parameters of each model were determined using the software Statistica, version 8.0, using the Quase-Newton method.

The physico-chemical parameters, $\mathrm{pH}$, soluble solids, total solids, ash and titratable acidity were determined according to the rules of the Adolfo Lutz Institute, IAL (2008). The pH was obtained by using a digital pH meter, Model ET-902 brand Digimed accurately $0.01 \mathrm{pH}$ units, previously calibrated with buffer solution $\mathrm{pH} 4.0$ and 7.0. The content of soluble solids $\left({ }^{\circ}\right.$ Brix) was determined using a bench type Abbe refractometer, brand Quimis model Q-109B. The solids were determined by weighing $20 \mathrm{~g}$ of the pulp at room temperature, followed by drying in an oven at $70{ }^{\circ} \mathrm{C}$ to constant weight. The method used to determine ash is the amount of inorganic substances obtained through the ash or the ash sample, based on the residue obtained by burning the sample in an oven at $525^{\circ} \mathrm{C}$. The total acidity of the product was determined by titrating the sample with a solution of 0.1 of $\mathrm{N}$ sodium hydroxide, expressing the final result as a percentage of citric acid.

Data analyses were treated according to completely randomized design with three replicates for each sample, using the program Assistat (SILVA \& AZEVEDO, 2006).

\section{RESULTS AND DISCUSSION}

\section{Physico-chemical characterization}

In Table 1 it is found the average values of physico-chemical whole pulp and with the addition of milk in different proportions.

TABLE 1. Values of physico-chemical parameters, with standard deviation, for whole annona pulp with different percentages of milk.

\begin{tabular}{|c|c|c|c|c|c|c|c|}
\hline \multicolumn{2}{|c|}{ Sample } & $\mathrm{pH}$ & $\begin{array}{c}\text { ATT } \\
\text { (\%citric acid) }\end{array}$ & $\begin{array}{c}\text { SST } \\
\left({ }^{\circ} \text { Brix }\right)\end{array}$ & $\begin{array}{l}\text { ST } \\
(\%)\end{array}$ & $\begin{array}{l}\text { Ashes } \\
(\%)\end{array}$ & SST/ATT \\
\hline Pulp & Milk & & & & & & \\
\hline $100 \%$ & $0 \%$ & $5.4 \pm 0.053$ & $0.417 \pm 0.065$ & $28.467 \pm 0.503$ & $29.108 \pm 0.467$ & $0.801 \pm 0.082$ & 68.266 \\
\hline $75 \%$ & $25 \%$ & $5.6 \pm 0.035$ & $0.357 \pm 0.042$ & $23.667 \pm 0.416$ & $24.012 \pm 0.224$ & $0.795 \pm 0.030$ & 66.294 \\
\hline $50 \%$ & $50 \%$ & $6.0 \pm 0.055$ & $0.344 \pm 0.046$ & $18.067 \pm 0.808$ & $20.005 \pm 0.250$ & $0.784 \pm 0.023$ & 52.520 \\
\hline $25 \%$ & $75 \%$ & $6.4 \pm 0.053$ & $0.270 \pm 0.014$ & $15.467 \pm 0.306$ & $15.727 \pm 0.765$ & $0.720 \pm 0.241$ & 57.285 \\
\hline
\end{tabular}

ATT- Total titrable acidity, TSS- Total soluble solids, ST- total solids

It is observed from Table 1 that the $\mathrm{pH}$ and total acidity of the whole pulp are within the range of values determined by SALGADO et al. (1999) for the same product which was 5.49 units of pH and acidity of 0.45 . The variation in physico-chemical composition of fruit juices is due to many 
factors such as variety, maturation stage, planting location, time of planting and harvesting, among others (SILVA et al., 2005).

It appears that the addition of milk to sugar-apple pulp brought to a higher $\mathrm{pH}$, corresponding to an increase in $\mathrm{pH}$ of the sample with a higher proportion of milk to $17.26 \%$. This is due to the $\mathrm{pH}$ of the milk being greater than that of the fruit pulp. The $\mathrm{pH}$ of the fruit in general is around 3.5. This value expresses the strength of the acids present in the juice which is correlated with a sensation of taste (VICENZI, 2006).

With respect to the total acidity of the integral sugar-apple pulp it was found that there was a decrease of $35.72 \%$ in the sample with $75 \%$ milk. This behavior was expected because the milk has low acidity which contributes to the dilution of organic acids existing in the pulp. Just as occurred with the total acidity, soluble solids also decreased with increasing proportion of milk in the samples. The total soluble solids ( ${ }^{\circ}$ Brix) of the sugar-apple pulp are in the same range of values determined by ALVES et al. (2000), UGULINO et al. (2005) for this product. The maximum reduction of soluble solids ( ${ }^{\circ}$ Brix) was $45.66 \%$, occurred in the sample with the highest percentage of milk.

The values of total solids of the whole pulp is greater than the value determined by UGULINO et al. (2005), decreases with increasing concentration of milk. There was a reduction of $49.4 \%$ of total solids in the sample with $75 \%$ milk in the fruit pulp. The ash content of the whole pulp fruit is $10.11 \%$ less than the sample with $75 \%$ milk.

The relationship between soluble solids and titratable acidity (TSS / TA) was higher in the whole pulp, followed by the sample with $25 \%$ milk and $75 \%$ of the fruit pulp. It is noted that the lower relation in relation to TSS / TA was observed in the composition of the sample with 50\% milk and 50\% pine pulp. SALGADO et al. (1999) found for the integral sugar-apple pulp values for TSS / TTA rate in order of 32.06, and the total soluble solids, TSS, were equal to $14.43^{\circ}$ Brix and total titratable acidity, TTA, $0.45 \%$. This ratio is well below that found in this study (68.266). This fact can be explained due to the high amount of soluble solids in the order of $28.4^{\circ}$ Brix.

\section{Rheological behavior}

\section{Effect of pulp temperature and concentration of the apparent viscosity}

Table 2 shows the parameter values of the Ostwald-Waelle (Power Law) and HerschelBulkley models obtained through the adjustment to experimental data for the whole sugar-apple pulp and pulp with different percentages of milk at temperatures of $0 ; 6 ; 12 ; 18$ and $24{ }^{\circ} \mathrm{C}$.

Analyzing the results in Table 2 for the Ostwald-Waele (Power Law) model, it appears that the parameter $\mathrm{k}$ (consistency index) of different samples at the same temperature increases with increasing pulp concentration, except for the whole pulp. Several factors affect the rheological behavior of fruit pulp, including temperature and concentration of soluble solids. Higher concentrations of pulp used in the formulations provide the concentration of soluble solids, and thus the amount of free water in the mixture decreases, thereby increasing the consistency and enhancing the stabilizing effect.

In this study it was found that the milk when added in small proportion (up to 25\%) causes a certain arrangement which increases the consistency of these samples. This fact was observed for samples of sugar-apple pulp with $25 \%$ of the whole milk at all temperatures. However, when the percentage is greater than $25 \%$, as expected, there is less consistency at all temperatures. Perhaps the high water content of the milk with the fat can occasion dilution, with consequent loss of consistency. Food materials are complex rheological structure consisting of a mixture of solids, liquids and structural components and any change in the content of these constituents may lead to changes sometimes unpredictable in its structure (OLIVEIRA et al, 2009; PEREIRA et al., 2008). 
TABLE 2. Adjustment parameters of Ostwald-de-Waelle (Power Law) and Herschel-Bulkley models, for whole annona pulp and annona pulp with different percentages of milk, as a function of temperature.

\begin{tabular}{|c|c|c|c|c|c|c|c|c|c|}
\hline \multirow{2}{*}{\multicolumn{2}{|c|}{ Concentration }} & \multirow{3}{*}{$\begin{array}{l}\text { Temp } \\
\left({ }^{\circ} \mathrm{C}\right)\end{array}$} & \multicolumn{3}{|c|}{$\begin{array}{l}\text { Ostwald-de-Waele } \\
\text { (Power Law) }\end{array}$} & \multicolumn{4}{|c|}{ Herschel-Bulkley } \\
\hline & & & $\mathrm{K}\left(\mathrm{Pas}^{\mathrm{n}}\right)$ & $n$ & $R^{2}$ & $\mathrm{~K}_{\mathrm{U}}(\mathrm{Pas})$ & $\mathrm{n}_{\mathrm{H}}$ & $\tau_{\mathrm{OH}}(\mathrm{Pa})$ & $\mathrm{R}^{2}$ \\
\hline Pulp & Milk & & & & & 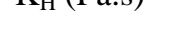 & & & \\
\hline \multirow{5}{*}{$100 \%$} & \multirow{5}{*}{$0 \%$} & 0 & 224.417 & 0.370 & 99.161 & 124.185 & 0.495 & 117.798 & 99.463 \\
\hline & & 6 & 209.313 & 0.375 & 99.180 & 115.600 & 0.502 & 110.801 & 99.481 \\
\hline & & 12 & 170.796 & 0.414 & 98.543 & 47.707 & 0.708 & 160.378 & 99.638 \\
\hline & & 18 & 158.888 & 0.420 & 98.647 & 48.942 & 0.691 & 142.900 & 99.544 \\
\hline & & 24 & 158.745 & 0.402 & 98.690 & 58.287 & 0.627 & 125.658 & 99.395 \\
\hline \multirow{5}{*}{$75 \%$} & \multirow{5}{*}{$25 \%$} & 0 & 309.578 & 0.285 & 99.843 & 249.439 & 0.324 & 63.601 & 99.875 \\
\hline & & 6 & 265.801 & 0.318 & 99.517 & 197.677 & 0.376 & 73.959 & 99.578 \\
\hline & & 12 & 246.571 & 0.322 & 98.919 & 156.387 & 0.413 & 98.502 & 99.046 \\
\hline & & 18 & 189.335 & 0.370 & 99.030 & 82.482 & 0.552 & 125.948 & 99.481 \\
\hline & & 24 & 162.994 & 0.390 & 98.640 & 44.913 & 0.684 & 148.010 & 99.679 \\
\hline \multirow{5}{*}{$50 \%$} & \multirow{5}{*}{$50 \%$} & 0 & 81.669 & 0.309 & 99.301 & 145.348 & 0.214 & 66.599 & 99.536 \\
\hline & & 6 & 66.987 & 0.351 & 99.773 & 54.859 & 0.391 & 13.519 & 99.804 \\
\hline & & 12 & 63.294 & 0.359 & 99.505 & 38.865 & 0.461 & 27.864 & 99.679 \\
\hline & & 18 & 52.733 & 0.398 & 99.536 & 42.791 & 0.441 & 11.624 & 99.570 \\
\hline & & 24 & 44.821 & 0.432 & 99.356 & 33.545 & 0.495 & 13.824 & 99.421 \\
\hline \multirow{5}{*}{$25 \%$} & \multirow{5}{*}{$75 \%$} & 0 & 14.849 & 0.311 & 99.038 & 23.208 & 0.239 & -9.140 & 99.616 \\
\hline & & 6 & 10.721 & 0.351 & 99.587 & 10.607 & 0.352 & 0.133 & 99.587 \\
\hline & & 12 & 10.430 & 0.354 & 99.657 & 11.695 & 0.333 & -1.474 & 99.664 \\
\hline & & 18 & 11.190 & 0.315 & 99.423 & 16.708 & 0.249 & -6.065 & 99.502 \\
\hline & & 24 & 9.109 & 0.357 & 99.546 & 8.406 & 0.372 & 0.836 & 99.550 \\
\hline
\end{tabular}

For the Herschel-Bulkley model, the results obtained for consistency index $\left(\mathrm{K}_{\mathrm{H}}\right)$ showed oscillations and without tendency defined in relation to concentration and temperature.

The values for the fluid behavior index $\left(n\right.$ and $n_{H}$ ), for Ostwald-de-Waelle and Hershel and Bulkley models, respectively, are below 1.0, characterizing the behavior of fluid mixtures as nonNewtonian and pseudoplastic, as it was expected, since such behavior is common in pulp and fruit juice, as reported by numerous authors as PEREIRA et al. (2008) in a study of the rheological behavior of umbu. BEZERRA et al. (2009) to analyze the model parameters for Hershel Bulkley rheological behavior of strawberry pulp found that all the $\mathrm{n}_{\mathrm{H}}$ values were also below 1.0, with values of at most 0.24 .

Pictures 1-2 are curves representing the shear tension as a function of strain rate, as described by the model of Ostwald-de-Waelle and Hershel Bulkley, respectively, obtained at different temperatures and concentrations. Based on statistical parameters analyzed $\left(\mathrm{R}^{2}\right)$, the adjustments of the two models to the experimental data are considered satisfactory.

It can be seen by analysis of the Figures 1 and 2 that with the increase of pulp concentration in the samples, the higher shear stress is required. This behavior is characteristic of a pseudoplastic fluid that follows the model of power (Power Law).With the increase of shear tension increases in the strain rate at all concentrations. It is also noted that inasmuch as the increase in the temperature, a decrease of the shear tension. OLIVEIRA et al. (2011) working with strawberry pulp and Pereira et al. (2008), working with umbu observed the same behavior. 

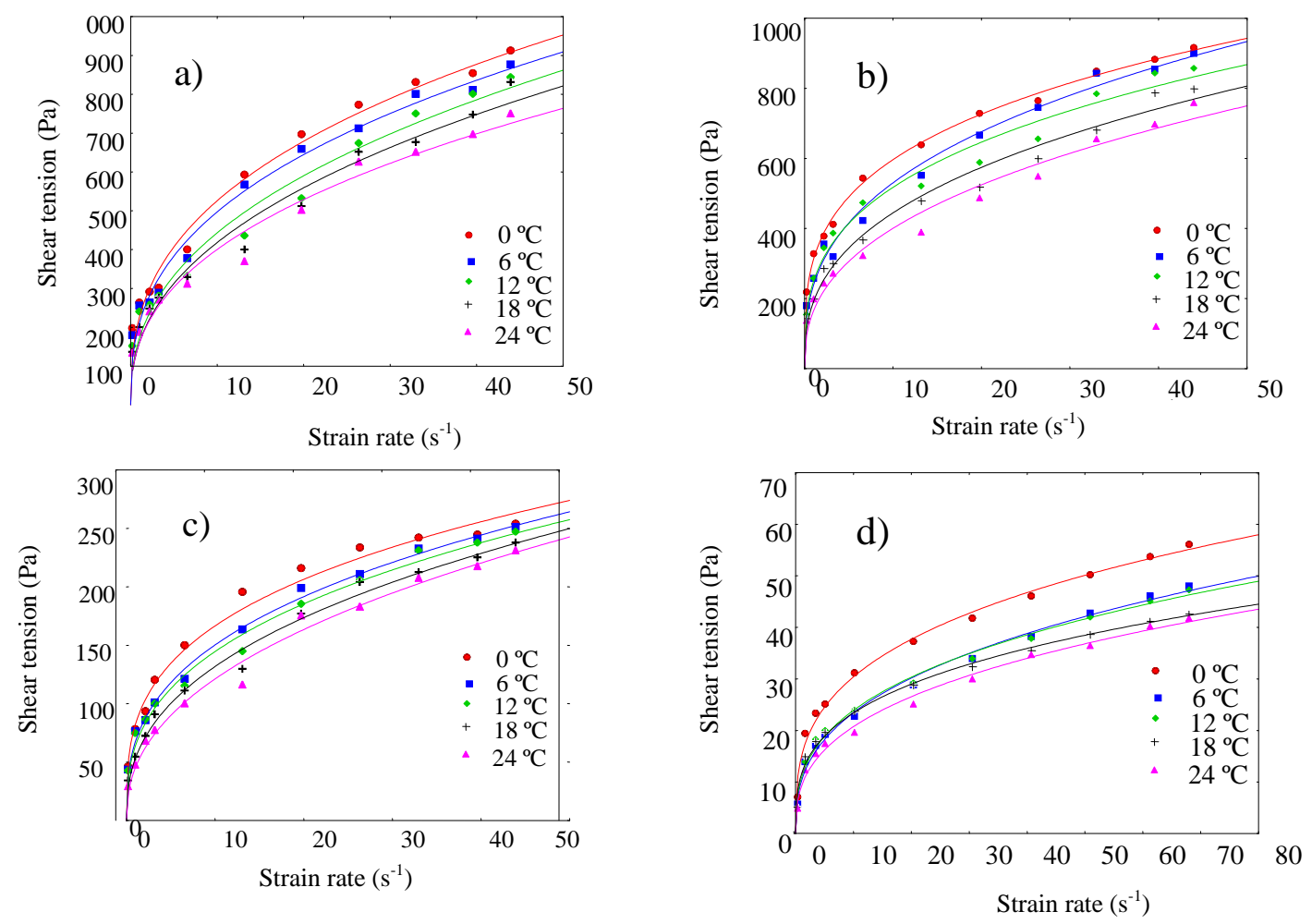

FIGURE 1. Relationship between shear tension and strain rate for samples with a concentration of annona pulp/milk as follows: a) $100 \%$ pulp and $0 \%$ milk; b) $75 \%$ pulp and $25 \%$ milk; c) $50 \%$ pulp and $50 \%$ milk; d) $25 \%$ pulp and $75 \%$ milk, described by the Ostwald-deWaelle model (Power Law) at different temperatures $\left(0 ; 6 ; 12 ; 18\right.$ and $\left.24{ }^{\circ} \mathrm{C}\right)$.
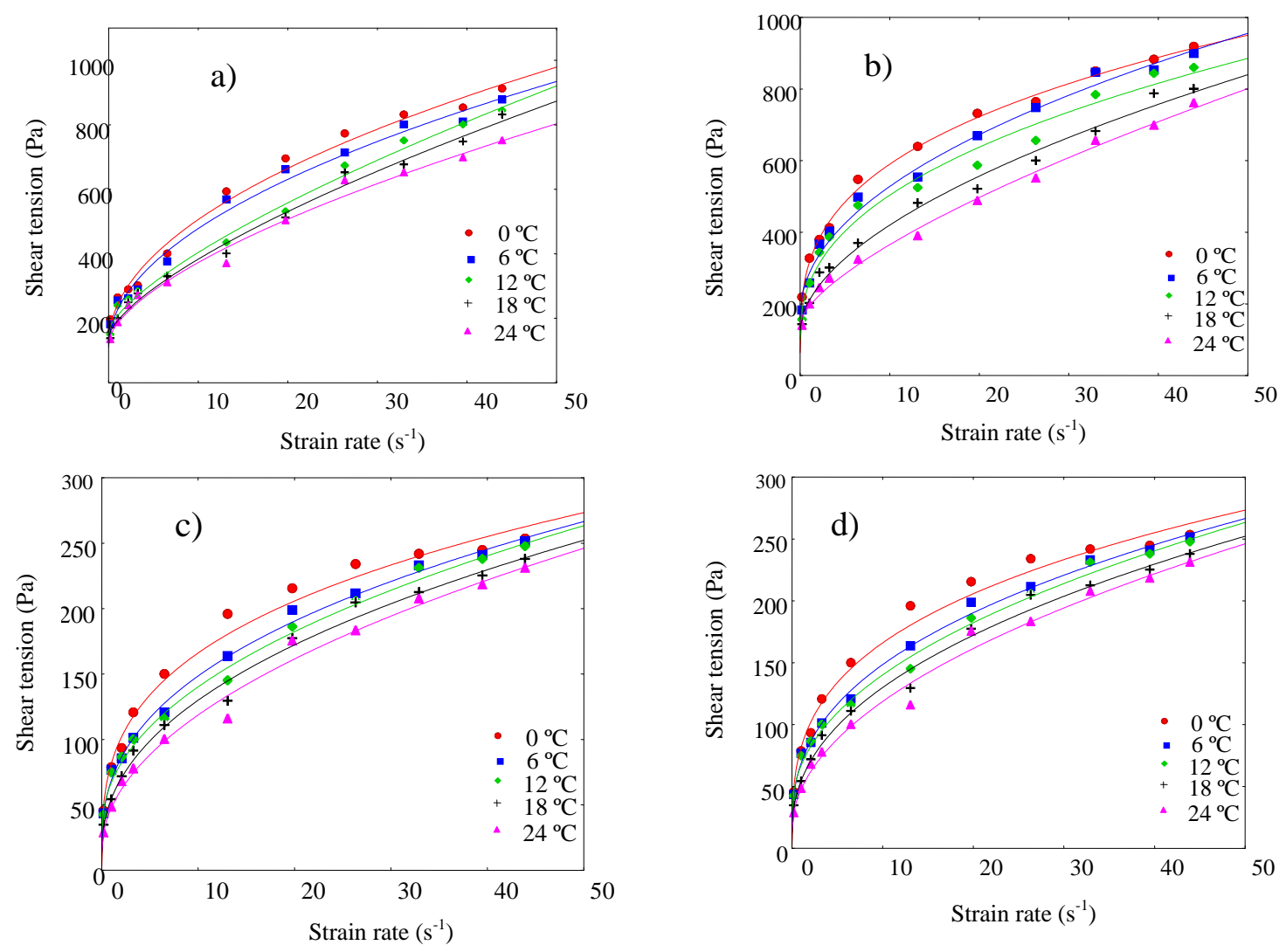

PICTURE 2. Relationship between shear tension and strain rate for samples with a concentration of annona pulp/milk as follows: a) $100 \%$ pulp and $0 \%$ milk; b) $75 \%$ pulp and $25 \%$ milk; c) $50 \%$ pulp and $50 \%$ milk; d) $25 \%$ pulp and $75 \%$ milk, described by the HershelBulkley model at different temperatures $\left(0 ; 6 ; 12 ; 18\right.$ and $\left.24{ }^{\circ} \mathrm{C}\right)$. 
It can be observed in Pictures 1 and 2 that for strain rates fixed, the shearing stress decreases as the temperature increases, indicating reduction of the apparent viscosity during the heating process.

Table 3 shows the values of apparent viscosity of the different mixtures annona / milk obtained for a rotation of $200 \mathrm{rpm}$ and a strain rate of $40 \mathrm{~s}^{-1}$ setting.

TABLE 3. Apparent viscosity of the annona pulp with different percentages of milk as a function of temperature.

\begin{tabular}{|c|c|c|c|c|c|c|}
\hline \multicolumn{2}{|c|}{ Concentration } & \multirow{2}{*}{$0^{\circ} \mathrm{C}$} & \multirow{2}{*}{$6^{\circ} \mathrm{C}$} & \multirow{2}{*}{$12^{\circ} \mathrm{C}$} & \multirow{2}{*}{$18^{\circ} \mathrm{C}$} & \multirow{2}{*}{$24^{\circ} \mathrm{C}$} \\
\hline Pulp (\%) & $\operatorname{Milk}(\%)$ & & & & & \\
\hline 100 & 0 & 2097.409 & 2041.682 & 1948.682 & 1888.409 & 1724.320 \\
\hline $75 \%$ & $25 \%$ & 2068.727 & 1990.591 & 1915.409 & 1817.727 & 1702.045 \\
\hline $50 \%$ & $50 \%$ & 575.909 & 571.136 & 560.909 & 539.772 & 524.318 \\
\hline $25 \%$ & $75 \%$ & 82.353 & 70.588 & 69.558 & 62.647 & 61.470 \\
\hline
\end{tabular}

It is noted from Table 3, a decrease in apparent viscosity with increasing temperature, at all concentrations and an increase in the apparent viscosity with increasing pulp concentration in the sample. The same behavior was observed by Oliveira et al. (2011) to study the rheological behavior of strawberry pulp; PEREIRA et al. (2008), working with umbu.

When the pulp concentration in the sample decreases the viscosity decreases intensely, indicating that the viscosity has a strong dependence on the solids content, a phenomenon also observed by GUEDES et al. (2010) studying the effects of temperature and concentration in the physical properties of the watermelon pulp.

The value of the apparent viscosity decreases with increasing temperature and increases with increasing concentration of solids. Many authors have observed this type of behavior such as GRANGEIRO et al. (2007), studying the viscosities of concentrated pulps of India-fig; BRANCO and GASPARETTO (2005) studied the rheology of mango pulp with different proportions of orange juice and acerola fruit; VIDAL et al. (2006) studied the rheological properties of the centrifuged mango pulp.

\section{CONCLUSIONS}

The rheological parameters initial tension and the viscosity increase with the addition of annona pulp, i.e. the increase in viscosity occurs with the increase in soluble solids content.

The apparent viscosity obtained by the Ostwald-Waelle (Power Law) and Hershel Bulkley model, for all formulations, decreased with the increasing of the strain rate and with the temperature increase.

The flow behavior index (n), determined by the rheological model of Ostwald-de-Waelle (power law) and Hershel Bulkley, had values lower than the unity under all conditions, which defines the sugar-apple pulp to different percentage of milk as a non-Newtonian fluid with timeindependent behavior and fitting into the pseudoplastic category (BEZERRA et al., 2009).

The models of Herschel-Bulkley and Ostwald-de-Waelle, based on statistical parameters, provided a good adjustment to experimental data. The flow behavior index determined through these models showed lower values than the unit, characterizing the whole annona pulp and the pulp with milk in the proportions pulp weight / milk weight of $75 / 25$ 50/50 and 25/75 as a nonNewtonian fluid with time-independent behavior and fitting into the pseudoplastic category. 


\section{REFERENCES}

ACAGA \& HAL. Pinha - Plano estratégico da indústria para 2006 a 2011. 2006. 24 p.

ALVES, R.E.; FILGUIERAS, H.A.C.; MOURA, C.F.H. Caracterização de frutas nativas da América Latina. Jaboticabal: UNESP/SBF, 2000. 66 p.

BEZERRA, J. R.M.; RIGO, M.; DEMCZUK JUNIOR, B.; CÓRDOVA, K. R. Estudo do efeito da temperatura nas propriedades reológicas da polpa de morango (Fragaria ananassa). Ambiência, Guarapuava, v.5, n.1, jan./abr. 2009.

BRANCO, I.G.; GASPARETTO, C.A. Comportamento reológico de misturas de polpa de manga e sucos de laranja e cenoura utilizando modelo de Casson, Brazilian Journal of Food Technology, Campinas, v.8, n.2, p.183-189, 2005.

FERNANDES, T.N.; RIBEIRO, F.C.R.; LEMOS, F.S.; PRADO, M.E.T.; RESENDE, J.V.; BELCHIOR, N.C. Comportamento reológico, parâmetros físico-químicos e dinâmica do congelamento da polpa de maracujá adicionada de sacarose e pectina. Brazilian Journal Food Technology, Campinas, v.12, p.43-50, jun. 2009.

GRANGEIRO, A.; QUEIROZ, A. J. de M.; FIGUEIRÊDO, R.M.F. de; CAVALCANTI MATA, M.E.R. Viscosidades de polpas concentradas de Figo-da-Índia. Revista Brasileira de Agrociência, Pelotas, v.13, n.2, p.219-224, 2007.

GUEDES, D.B.; RAMOS, A.M.; DINIZ, M.D.M.S. Efeito da temperatura e da concentração nas propriedades físicas da polpa de melancia. Brazilian Journal of Food Technology, Campinas, v.13, n.4, p.279-285, 2010.

INSTITUTO ADOLFO LUTZ. Normas Analíticas: métodos químicos e físicos para análise de alimentos. 4.ed. São Paulo, 2008. v.1, 1020 p.

OLIVEIRA, R.C. de; BARROS, S.T.D. de; ROSSI, R.M. Aplicação da metodologia bayesiana para o estudo reológico da polpa de uva. Revista Brasileira de Produtos Agroindustriais, Campina Grande, v.11, n.1, p.73-80, 2009.

OLIVEIRA, R.C. de; ROSSI, R.M.; BARROS, S.T.D. de. Estudo do efeito da temperatura sobre o comportamento reológico das polpas de gabiroba e goiaba. Acta Scientiarum, Maringá, v.33, n.1, p.31-37, 2011.

PEREIRA, E.A.; BRANDÃO, E.M.; BORGES, S.V.; MAIA, M.C.A. Influence of concentration on the steady and oscillatory shear behavior of umbu pulp. Revista Brasileira Engenharia Agrícola e Ambiental, Campina Grande, v.12, n.1, p.87-90, 2008.

SALGADO, S.M.; GUERRA, N.B.; MELO FILHO, A.B. Polpa de fruta congelada: efeito do processamento sobre o conteúdo de fibra alimentar. Revista de Nutrição, Campinas, v.12, n.3, p.303-308, 1999.

SANTANA, M.T.A.; SIQUEIRA, H.H.; REIS, K.C; LIMA, L.C.O.; SILVA, R.J.L.Caracterização de diferentes marcas de suco de uva comercializados em duas regiões do Brasil. Ciência e Agrotecnologia, Lavras, v.32, n.3, p.882-886, 2008.

SATO, A.C.K.; CUNHA, R.L. Influência da temperatura no comportamento reológico da polpa de jabuticaba. Ciência e Tecnologia de Alimentos, Campinas, v.27, n.4, p.879-884, 2007.

SILVA, F. de A.S.; AZEVEDO, C.A.V. de. A new version of the Assistat -Statistical Assistance Software. In: WORLD CONGRESS ON COMPUTERS IN AGRICULTURE, 4., 2006, Orlando. Proceedings... Reno: American Society of Agricultural and Biological Engineers, 2006. p.393-396.

SILVA, F. C.; GUIMARAES, D.H.P.; GASPARETTO, C.A. Reologia do suco de acerola: efeitos da concentração e temperatura. Ciência e Tecnologia de Alimentos, Campinas, v.25, n.1, p.121-126, 2005. 
TORALLES, R.P.; VENDRUSCOLO, J.L.; VENDRUSCOLO, C.T. Reologia de urê homogeneizado de pêssego: efeito da temperatura e concentração. Brazilian Journal of Food Technology, Campinas, v.9, n.1, p.1-8, 2006.

UGULINO, S.M.P.; GOUVEIA, D.S.; FIGUEIREDO, R.M.F.; TORRES, E.K. Caracterização físico-química da polpa da pinha integral e com adição de diferentes concentrações de leite. In: SIMPÓSIO BRASILEIRO DE PÓS-COLHEITA DE FRUTOS TROPICAIS, 2005, João Pessoa.

VICENZI, R. Tecnologia de frutas e hortaliças: química industrial de alimentos. Ijuí: Universidade Regional do Noroeste do Estado do Rio Grande do Sul, 2006. 73 p.

VIDAL, J. R. M. B.; SIERAKOWSKI M. R.; HAMINIUK, C.W.I.; MASSON, M.L.Propriedades reológicas da polpa de manga propriedades reológicas da polpa de manga (Mangifera indica $\mathrm{L}$. Cv. Keitt) centrifugada. Ciência e Agrotecnologia. Lavras, v.30, n.5, p.955-960, 2006. 